correspondingly lower 'crude protein' (including any undigested nitrogenous debris), suggests more direct passage through the gut with limited sojourn at the sacculus end of the cæcum.

The broad statement by Madsen ${ }^{2}$ and by Taylor ${ }^{2}$ that the two types of frces are due to variations in "intestinal rhythm" provides no explanation of the actual sequence of events. The sequenee now suggested is a partial filling of the deeper regions of the cæcum as the food contents pass on from the small intestine, associated with a partial more direct passage of digested material into the colon during the day, followed by extensive emptying of the deeper regions of the cæcum at night. The more regular passage of 'day' material presumably gives time for greater inspissation and a drier residue, the wetter 'night' freces being accounted for by more rapid discharge of the deeper cæcal contents.

According to this view, the 'day' fæces would represent less completely digested food debris and this might be expected to be the portion more readily re-eaten. Although some 'day' fæeces are reconsumed, the striking feature is the total disappearance of the more fully digested 'night' fæces when the inhibiting collar is removed. The 'night' fæces, however, are rich in protein and presumably swarming with bacteria capable of attacking cellulose. Is this of any advantage to the rabbit?

Veterinary Laboratory,

A. Eden. New Haw,

Weybridge, Surrey. March 26.

${ }^{1}$ NATURE, 145, 36 (1940).

2 NatUre, 143, 981-982 (1939).

\section{Male Behaviour of the Female Starling (Sturnus v. vulgaris, L.) in Autumn}

Witschi and Miller ${ }^{1}$ have shown experimentally that the yellow bill colour of the starling in the breeding season is induced by male sex hormone. This yellow colour does not develop after the removal of the ovary or the testes, but in such castrated animals it may be induced in either sex by injections of androgenic substances. (Estrogenic substances have no effect on bill colour. It is concluded that the ovary produces male sex hormone, and that the most prominent secondary sexual character of the female starling is in fact a male character.

It has now been observed that the bills of adult British starlings of both sexes begin to turn yellow at the end of October, the time when the testes first show signs of activity. As the change in bill colour is a specific indication of the presence of androgenic substances, it is clear that in autumn both ovaries and testes are secreting male sex hormone. This has been found to have a marked effect on behaviour. At this time of year there is a burst of song which continues throughout November, and although in the breeding season the male alone sings, in autumn the habit is also developed by the female. This has been established partly by observation and partly by the examination of birds shot while singing. A similar effect has been produced experimentally by Leonard ${ }^{2}$, who showed that the female canary, Serinus c. canarius (L.), when injected with male sex hormone, sings like the male. The song of the starling decreases in volume in December and January, particularly in severe weather, and when, in late February, it again increases it is produced by the male alone. At this time the ovary is growing and is probably secreting female sex hormone in such quantity that any effect on behaviour due to the presence of male sex hormone is obscured. The continued yellow coloration of the bill is proof; however, that male sex hormone is still being produced in the female bird.

The autumn change in bill colour, with its associated behaviour, occurs only in the British starling. The Continental birds present in the British Isles in autumn and winter retain the dark bill until January, and there is no autumn song by either sex. It has already been shown (Bullough and Carrick ${ }^{3}$; and unpublished) that the gonads of these immigrant starlings mature later in the season than those of the British birds.

The occurrence of male behaviour in autumn has been observed in the females of several other species of birds, and it is probable that these, like the female British starling, are under the influence of male sex hormone. In the robin, Erithacus rubecula melophilus, Hart., for example, Lack ${ }^{4}$ has shown that in autumn individuals of each sex stake out territories and hold them with fighting and song. In this species, as in the starling, normal female behaviour reasserts itself early in the year when the female birds abandon their own territories and enter those of the males. This apparently widespread phenomenon of male behaviour on the part of female birds in autumn has proved difficult to explain in terms of ecological factors alone, and it is probable that other aspects of animal behaviour will be better understood when it becomes possible to correlate them with the condition of the endocrine balance.

$$
\begin{array}{cl}
\text { University of Leeds. } & \text { W. S. BULlough. } \\
\text { March } 9 . & \text { R. CARRICK. }
\end{array}
$$

${ }^{1}$ Witschi, E., and Miller, R. A., J. Exp. Zool., 79, 475 (1938). ${ }^{2}$ Leonard, S. L., Proc. Soc. Exp. Biol. Med., 41, 229 (1939).

${ }^{3}$ Bullough, W. S., and Carrick, R., NATURE, 144, 33 (1939).

4 Lack, D., Proc. Zool. Soc., A, 109, 169 (1939).

\section{Chalk Landscape}

THE communication of Lord Kennet of the Dene ${ }^{1}$ reminds me of a note I wrote recently in an account of the ice storm of the end of January and of the thaw that occurred a week later. On the evening of February 3 rain began and by the morning of February 4 there was a strong thaw. But the ice below the snow and the frozen ground did not let the water soak away, with the result that there was much flooding. In the Cotswolds water poured over the frozen slopes, and at Bagendon the valley became a raging torrent four to five feet deep. Even here, $700 \mathrm{ft}$. above the sea, there was much flooding and for a time some roads were impassable. It has occurred to me more than once when watching the run off of water in a thaw after the ground has been frozen that such scenes must have occurred in the south of England on a much larger scale every spring during the Ice Age, and I have wondered whether this may not have contributed, or may not have been the chief cause, in the formation of the dry valleys of the chalk country.

Stoner Hill,

C. J. P. Cave.

Petersfield.

March 24.

' NATURE, 145, 466 (March 23, 1940). 